\title{
Peri-urbanisation and multifunctional adaptation of agriculture around Copenhagen
}

\author{
Ingo Zasada, Christian Fertner, Annette Piorr \& Thomas Sick Nielsen
}

\begin{abstract}
Peri-urbanisation, as a process of the physical expansion of settlement areas but also socio-economic transformation, has been recognised as a major spatial development beyond the urban fringes. Agriculture, the main land use actor in the hinterlands of many urban areas is increasingly affected by urban encroachment, responds with adaptation strategies and farming activities to cope with the peri-urban framework conditions. Adaptation pathways encompass specialisation into horticulture as well as enhanced environmental and lifestyle orientation of farming - typical elements of multifunctional agriculture. However, due to the heterogeneity of the periurbanisation processes also differences in farming transition are expected. Based on a differentiation into displaced-urbanisation, ex-urbanisation, anti-urbanisation and hidden-urbanisation as main types of peri-urbanisation, variances of farming responses are elaborated for municipal entities in the Copenhagen region in Denmark using statistical census data. Under consideration of location determinants, regression models have been applied to analyse the inter-relationship between different peri-urbanisation processes and multifunctional farming activities. Findings confirm that the differentiation of peri-urban processes is meaningful for the explanation
\end{abstract}

of spatial distribution of farm adaptation strategies, particularly in the case of leisure and environmental oriented farm practices.

\section{Key words}

Rural in-migration, urban-rural-relationship, post-productivism, spatial variation, regression model, farm strategy.

Ingo Zasada (Corresponding author)

Annette Piorr

Leibniz-Centre for Agricultural Landscape Research, Müncheberg, Germany

E-mail: ingo.zasada@zalf.de

Christian Fertner

Thomas Sick Nielsen

Danish Centre for Forest, Landscape and Planning, University of Copenhagen, Denmark

Geografisk Tidsskrift

Danish Journal of Geography 111(1): 59-72, 2011

\section{Introduction}

The integration of rural areas surrounding cities into urban regions represents a common spatial development phenomenon in Europe in the recent decades. Physical conversion of open space - in particular agricultural land - for urban purposes and socio-cultural transitions in rural areas through adoption of urban life styles or in-migration of urban dwellers, leads to the establishment of a peri-urban space, and sets different forms of urban and rural living and working into close contact. However, it has been argued that, although under pressure and often marginalised, agriculture has responded to the peri-urban framework conditions by introducing post-productive, consumption-oriented adaptation of farming activities.
In-migration and socio-cultural changes represent relevant drivers for the development of agriculture in peri-urban areas around Copenhagen region (Primdahl, 1999; Busck et al., 2006; Præstholm \& Kristensen, 2007). Although a distinct cause-effect relation might not exist, a mutual influence of peri-urbanisation and agriculture has been observed. The central research objective of this paper is to explore the relationship between the heterogeneous types of peri-urbanisation processes (ex-, displaced-, anti- and hidden-urbanisation) and effects on agricultural activity. More specifically, it aims at analysing the spatial co-existence of peri-urbanisation types and the extent of multifunctional farm adaptation, such as small-scale, high-value farming systems, the farmers' participation in landscape management and agri-environmental measures as well as the recreational and lifestyle orientation in peri- 
urban areas. From this objective, two main research questions have been derived:

(1) Do ex-, displaced-, anti- and hidden-urbanisation contribute to differentiate processes of peri-urbanisation in the municipalities around Copenhagen? To which extent do location determinants, such as distance to the urban centre, urban form or natural amenities influence the spatial distribution of these processes?

(2) Does the spatial distribution of different peri-urbanisation processes explain the variances in the extent of multifunctional farming, consisting of (a) specialisation in high-value cropping pattern, (b) participation in agri-environmental practices and (c) diversification in recreational services and lifestyle-oriented farming?

\section{Peri-urbanisation}

Neglected for a long time, the notion of peri-urban area has been introduced to describe the heterogeneous pattern of settlement pattern at the urban-rural interface, replacing the former model of an urban-rural dichotomy (Errington, 1994). From a European perspective peri-urban areas are often understood as mixed areas under urban influence but with a rural morphology (Caruso, 2001). The Council of Europe once defined the peri-urban sphere as a transition area moving from strictly rural to urban (CEMAT, 2007). On the other hand, it is far from ephemeral, but instead forms new kinds of permanent landscape (Antrop, 2000). Changes in peri-urban space are often results of a high pressure towards urban development (Bertrand, 2007). But this development is not necessarily limited to physical urban development. It is also characterised by the emergence of urban lifestyles in rural areas like hobby farming and second homes (Caruso, 2001; Briquel \& Collicard, 2005). Such transformations which take place outside the urban cores can be summarised by the term peri-urbanisation. However, with this very broad definition, peri-urbanisation overlaps and coincides with many other phenomena and dynamics elaborated and described by researchers in the last decades. Besides commercial and infrastructure development, the internal migration pattern represents a major driver for periurbanisation. Especially the process of counter-urbanisation is very relevant for the transition of peri-urban areas. Counter-urbanisation describes a migration from the city to the countryside and was first observed in the 1960s and 1970s in the United States and Western Europe. Champion et al. (1989) emphasised that it is not a unidirectional movement but a tendency towards de-concentration, resulting from a complex pattern of flows. Among others, Mitchell (2004) further elaborated the concept by identification of three different processes of counter-urbanisation dependent on different motivations of the migrants.

Several authors (e.g. Spectorsky, 1955; Halfacree \& Boyle, 1998) have defined ex-urbanisation as a process of in-migration of affluent people into rural settings. Staying within close commuting distance, they usually keep their job and daily routines. As a second type, displaced-urbanisation is characterised by out-migration of people based on economic necessities, such as affordable housing, job availability, security and health considerations (Mitchell, 2004). Displaced-urbanisation typically refers to low income groups or young families who cannot afford suitable housing and living environment in the inner city. Rather different from the previous, anti-urbanisation represents the third type of counter-urbanisation. Mitchell (2004) extends the concept from Halliday \& Coombes (1995) who used the term to describe urban dwellers moving out into the countryside to escape urban lifestyle. She identified three sub-variants - self-sufficient lifestyle, relocation to enhance quality of life and amenity driven retirement migration.

Ex-urbanisation, displaced-urbanisation and anti-urbanisation represent migratory movements into peri-urban areas. Another urbanisation process refers to socio-cultural changes of the local residents, such as the adoption of urban life styles by the rural population as described by Antrop (2004), Primdahl (1999) and lately in an empirical analysis of another region in Denmark by Madsen et al. (2010). Although acknowledged as important for the transformation of peri-urban areas, only little physical land use changes can be observed. That is why scholars refer to it as hiddenurbanisation. The term was originally introduced by Lewan (1969) and later by van den Vaart (1991) to describe the functional change and conversion of farmsteads by new inhabitants but also the changed behaviour of the local residents. It includes increasing intra-regional relationships in terms of work, trade or leisure, even in peripheral subregions, caused by improved accessibility or the change of local conditions.

\section{Multifunctional farm adaptation in peri-urban areas}

During the recent decades societal transitions in peri-urban areas towards enhanced environmental consciousness, urban lifestyles and the rise of an aging and leisure-oriented society are challenging the predominant mono-functional 
production agriculture (Wilson, 2007). Increased standards of living and available leisure time are reflected by a tendency to buy regional organic food, spend time or even permanently settle down in the near countryside (Primdahl, 1999). Following the European model of multifunctional agriculture for the joint production of commodities and non-commodities (Piorr et al., 2007) or the provision of multiple social, environmental and economic functions (Van Huylenbroeck et al., 2007), organic farming and landscape management, tourism and hobby farming as well as diversification into other gainful activities beyond pure food and fiber production have continuingly gained importance - particularly in peri-urban areas (Zasada, 2011). Multifunctional farm adaptation in peri-urban areas had been comprehensively studied, focusing on specific farm types (Busck et al., 2006; Præstholm et al., 2006), institutional environment (Vandermeulen et al., 2006) or farm holders characteristics, such as age, education and attitudes (Jongeneel et al., 2008). Other scholars have also taken the question of urban location and density into consideration (Beauchesne \& Bryant, 1999; Van Huylenbroeck et al., 2005; Tobias et al., 2005). A tendency was observed that especially peri-urban farmers tend to respond by adapting activities and improve the individual business situation. Also new peri-urban residents have been attracted to start diversification activities, when purchasing farm properties (Præstholm \& Kristensen, 2007). Others have interpreted the multifunctional impacts of changes in peri-urban agriculture both from a territorial as well as from an individual farm point of view. Van Berkel \& Verburg (2010) for instance described the multifunctional potential of European regions in relationship to the territorial capital as a mix of agricultural, tourism and off-farm employment. For a number of European metropolitan regions, they identified distinctive clustering of multifunctional capacity around large urban centres due to urban demand for multiple rural services.

Due to the proximity and access to consumer groups, peri-urban agriculture is promoted by intensive urban-ruralrelationships. Results from a recent German survey on structures and trends in organic vegetable production underline the high relevance of direct marketing, as countrywide a large share of organic horticultural holdings sell to the consumer directly (Goy \& Maack, 2008). For individual farm holdings, the proximity to urban areas encourages the identification of market niches, innovation and adaption to new demands, as Cabus \& Vanhaverbeke (2003) point out. Accordingly, high productivity and specialisation, focusing on horticultural high-value produces, such as fruits, vegetables or ornamental plants has been observed in North American (Bryant et al., 1992) and European peri-urban regions (Péron \& Geoffriau, 2007). The implementation of landscape management or ecological compensation measures has been also studied in various peri-urban areas, providing evidence for higher participation rates than in other rural areas (Busck et al., 2006; Tobias et al., 2005). More controversy exists on the question of allocation of organic farming in peri-urban areas. Whereas Beauchesne \& Bryant (1999) and Ilbery et al. (1999) recognised a concentration of organic producers near urban areas in Canada and the UK, Tobias et al. (2005) found rather under-representation in Swiss urban agglomerations, due to the low suitability of small-scale farm structure.

Within the agricultural transition debate, particularly the rise of the post-productive paradigm is discussed, where the agricultural activity itself is even conceived as recreational activity decoupled from any economical farming motivation (Primdahl, 1999). Agricultural census results from Denmark have shown a significant increase of phenomena such as part-time, hobby and retirement farming (Præstholm \& Kristensen, 2007; Busck et al., 2008). Referring to the provision of recreational services, holding and breeding of horses for leisure purposes has been recognised as an increasing income source in peri-urban agriculture (Bailey et al., 2000). Empirical research in the UK, Canada and Sweden indicates significantly higher densities of horses and horse-farms in peri-urban fringes of metropolitan areas compared to other rural areas (Quetier \& Gordon, 2003; Elgaker \& Wilton, 2008).

\section{Methodology and database}

\section{Study area}

The case study region for this analysis encompasses an area in the east of Denmark of around $9,000 \mathrm{~km}^{2}$, including the islands of Sjaelland - with the Danish capital Copenhagen Lolland, Falster, Møn and some minor islands. The regional population has experienced a considerable growth since the 1990s, accompanied by migration of certain groups such as families (Aner, 2009) and retirees (Herslund \& Fertner, 2010) to the countryside. Most changes in agricultural land use were observed in areas nearby Copenhagen, the urban core of the region (Præstholm \& Kristensen, 2007; Busck et al., 2008). A very visible change represents the ongoing development of summer houses and second homes along the coast of the region. Many people have moved and still move in their summer house after retirement in the follow 
of the change of $\S 41$ in the Danish Planning Law in 1991. The development of new infrastructure expanded the urban area of Copenhagen in recent decades, establishing one big commuter zone (Nielsen \& Hovgesen, 2005) like many other monocentric city-regions throughout Europe.

Not only limited to the urban fringes of Copenhagen, but also occurring all over the region in different forms, this process accounts for a substantial impact on agriculture which covers around $70 \%$ of the total area. An analysis of CORINE Land use data (EEA) for the year 1990-2006 illustrates some of the major trends in the region. The area of artificial surfaces covering settlement, industry and infrastructure has expanded by $7.2 \%$ region-wide. This has basically taken place at the expense of arable land, located close to the urban area and zoned for urban purposes. Forest area marginally decreased whereas pasture and shrubland has enlarged by $14.8 \%$ and $17.0 \%$. Related to the increasing valorisation of extensive grassland production, agricultural land utilised for the production of cereals has been reduced from $63 \%$ to $57 \%$, whereas the area share of horticulture is rather constant. Due to the intensivation of production, the farm structure has been subject to tremendous transitions. Similar to Danish national figures, the average farm size in the case study area has been nearly doubled from below 30 ha to almost 60 ha between the beginning of the 1980s and 2004 - at a time before the decoupling of single farm payments of the Common Agricultural Policy (CAP) was implemented.

However, according to figures of the Danish statistical office (Danmarks statistik), in 2003 around 20\% of all farms in the case area diversified into non-agricultural activities compared to $15 \%$ in the whole of Denmark. In the area nearest to Copenhagen the share is even around $25 \%$ and has almost doubled since 1998 . The typical nonagricultural activities are agricultural services (e.g. use of equipment and machinery). Though, especially direct marketing, riding schools and further processing has considerably increased over the recent years in the case area. Kristensen (2001) has observed intensification and specialisation processes in agriculture in the case study area leading to a decrease arable farming and an increase of horticulture already in the 1980s. Throughout the 1980s and 90s Præstholm \& Kristensen (2007) found also farm extensification in this area, related to a shift towards parttime and hobby farming.

\section{Data sets and analytical model}

The analysis is conducted at the spatial level of municipal entities, as it represents the most detailed level, where statistical data on both the process of peri-urbanisation as well as farming structure is available. Socio-economic data (Danmarks Statistik Statistikbanken; Danmarks Statistik,

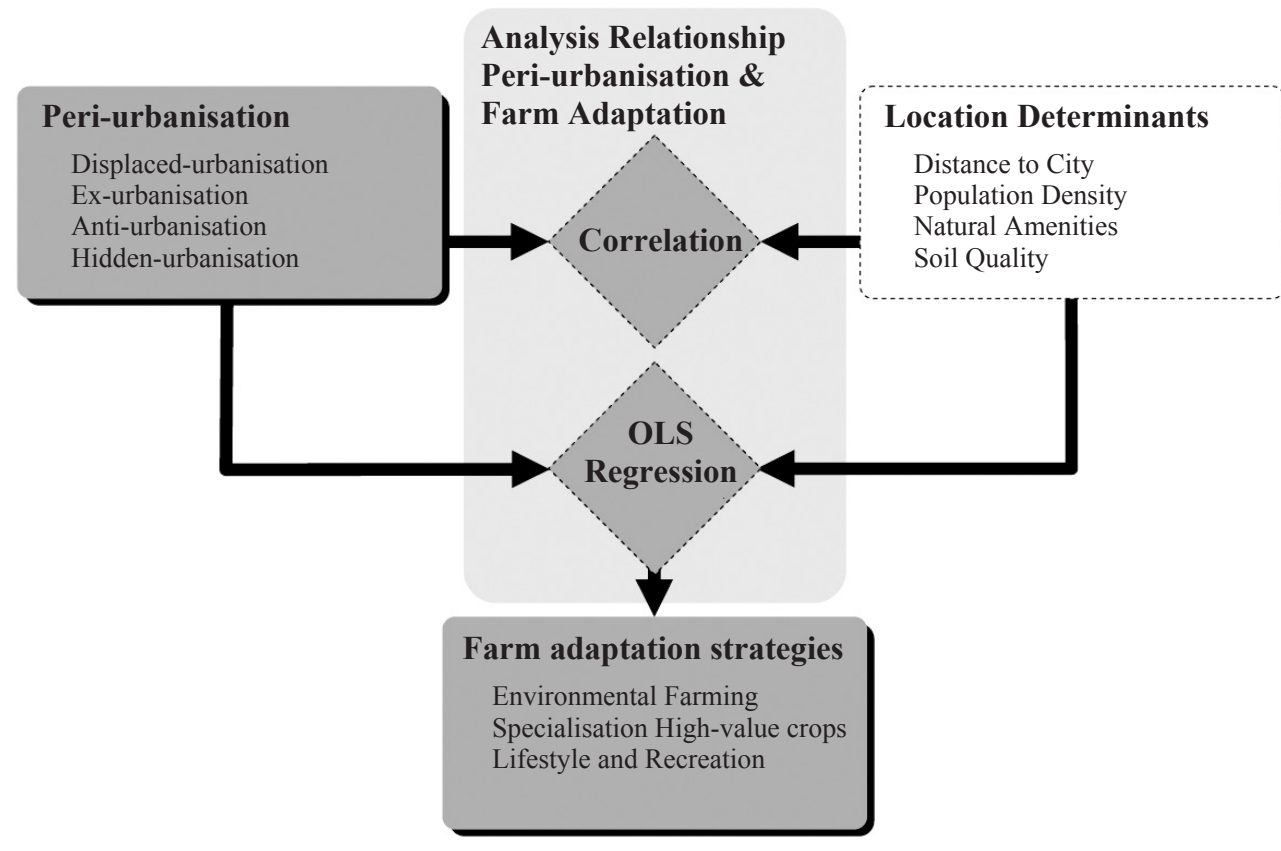

igure 1: Analytical framework. 
1989) of all 95 municipalities (situation before municipal reform in 2007) in the case study region, excluding the urban core municipalities of Copenhagen and Frederiksberg were included for the time span of 1986 to 2006.

To address the research questions outlined above, the analytical model for this study integrates the four different types of peri-urbanisation as well as location framework conditions, represented by location determinants as explanatory variables. Through multivariate statistical analysis both are used to explain the value distribution of multifunctional farm adaptation measures in the municipalities of the case study region. The main component is a regression analysis of peri-urbanisation and farm adaptation variables. Location determinants are integrated in the regression analysis to control for their influence. As preliminary step we conducted a correlation analysis of peri-urbanisation variables and location determinants to characterise their patterns (Figure 1).

As a first step, one socio-economic proxy variable was chosen for each type of peri-urbanisation as explanatory variable in the analytical model (Table 1). The variables cannot cover the full spectrum of the respective periurbanisation process as described in literature, but the represent relevant elements of the process. As proxy indicator for ex-urbanisation the in-migration of persons with an income above average was chosen. Applying the indicator for a 20-year period, a different threshold for the period 1986-1996 than for 1996-2006 to account for the observed increase in the average income over time was necessary. Displaced-urbanisation is illustrated by in-migration of children below six years, representing families with small children. Families are constrained by several factors in their housing choice - not just economically but also by the availability of social infrastructure or a safe and green environment. An alternative would be to look at the in-migration of persons with under average income. However, this indicator does less comply with the idea if displaced-urbanisation as it only focuses on the financial situation of persons and no other push factors as safety or environmental concerns. People with the least income often migrate to very remote, typically small town areas and are not dependent on certain urban infrastructure like families but mainly on public transfers. Anti-urbanisation is represented by the in-migration of persons between 60-69 years. As the normal retirement age in Denmark is 65 , these are typically retirees. Finally, to illustrate a facet of hidden-urbanisation, we calculated the increase (or decrease) of residents shifting from a local employment to commuting to a different municipality during the analysis period. This should illustrate the change of interrelations in the case study region in respect to working. Making use of correlation analysis, the spatial allocation of the peri-urbanisation processes was studied with the help of location determinants which explain the heterogeneity of the case study area in terms of urbanisation and urban form on the one side as well as bio-physical conditions, such as soil quality and natural amenities on the other side. Insights of the relationship with location determinants are

Table 1: Peri-urbanisation processes and proxy indicators used.

\begin{tabular}{|l|l|l|}
\hline Peri-urbanisation process & \multicolumn{1}{|c|}{ Characteristics } & \multicolumn{1}{|c|}{ Proxy indicator used } \\
\hline Ex-urbanisation & $\begin{array}{l}\text { Wealthy urbanites moving into the countryside } \\
\text { (Spectorsky, 1955; Mitchell, 2004) }\end{array}$ & $\begin{array}{l}\text { In-migrants with income above average: } \\
\text { Yearly income >200,000 DKK (1986-1996) } \\
\text { resp. >250,000 DKK (1996-2006) } \\
\text { / relative to total population in 1986 }\end{array}$ \\
\hline Displaced-urbanisation & $\begin{array}{l}\text { Migration due to necessity, (employment, liv- } \\
\text { ing costs, housing availability), Young families } \\
\text { (Mitchell, 2004) }\end{array}$ & $\begin{array}{l}\text { In-migrants 0-5 years 1986-2006 } \\
\text { / relative to total population in 1986 }\end{array}$ \\
\hline Anti-urbanisation & $\begin{array}{l}\text { Self-sufficient lifestyle, preferring smaller com- } \\
\text { munities, amenity-driven retirement migration } \\
\text { (Robinson, 1990; Halliday \& Coombs, 1995; } \\
\text { Mitchell, 2004) }\end{array}$ & $\begin{array}{l}\text { In-migrants 60-69 years 1986-2006 } \\
\text { relative to total population in 1986 }\end{array}$ \\
\hline Hidden-urbanisation & $\begin{array}{l}\text { Non-agricultural activities, conversion of farm- } \\
\text { steds, commuting due to economic reasons } \\
\text { (Lewan, 1969; van den Vaart, 1991) }\end{array}$ & $\begin{array}{l}\text { Change of commuters 1986-2006 minus } \\
\text { change of employees 1986-2006 }\end{array}$ \\
\hline
\end{tabular}

Data sources: Danmarks Statistik Statistikbanken; Danmarks Statistik (1989) 
Table 2: Multifunctional farming activities.

\begin{tabular}{|c|c|c|}
\hline Adaptation Strategy & Agricultural Activity & Indicator \\
\hline \multirow[t]{2}{*}{ Specialisation on high-value produces } & Greenhouse production & $\begin{array}{l}\text { Share of greenhouse area of total UAA } 2005 \\
\text { (in \%) }\end{array}$ \\
\hline & Horticultural production & $\begin{array}{l}\text { Share of horticulture area of total UAA } 1999 \\
\text { (in \%) }\end{array}$ \\
\hline \multirow[t]{2}{*}{ Agri-environmental orientation } & Organic production scheme & $\begin{array}{l}\text { Share of organic farming area from total UAA } \\
2003 \text { (in \%) }\end{array}$ \\
\hline & Extensive grassland cultivation & Share of grassland from total UAA 2003 (in \%) \\
\hline \multirow[t]{2}{*}{ Lifestyle and recreational farming } & Density of horse-keeping & Number of horses 1999 (per ha UAA) \\
\hline & Part-time and leisure farming & Share of holdings < 10 ha 1999 (in \%) \\
\hline
\end{tabular}

UAA = Utilised Agricultural Area

Data sources: Danmarks Statistik (2000); Institut for Jordbrugsproduktion og Miljø; Kort \& Matrikelstyrelsen; Miljøministeriet

important as they affect both the peri-urbanisation and farming activities.

Within the second step of the analytical model, a set of six variables which represent multifunctional farm adaptation was selected - specialisation on high-value produces, environmental orientation and the focus on leisure activities. The variables have been derived from statistical census data (Danmarks Statistik, 2000) and complemented by regional geo-information data on agricultural land use (Institut for Jordbrugsproduktion og Miljø; Miljøministeriet) for the situation towards the end of the observed periurbanisation process. Agricultural data on municipality level is collected by different institutions in Denmark and not always in the same frequency. Therefore the datasets used in this analysis originate from the period 1999-2005 to achieve temporal compliance with the peri-urbanisation processes (Table 2).

To analyse the influence of the different types of periurbanisation on the spatial distribution of the multifunctional farm adaptation, linear ordinary least square (OLS) regression models have been derived including farming variables as depending and variables of peri-urbanisation and location factors as predictor variables. Strength and direction of the influence of the predictor variable is represented by the estimated standardised coefficient $\beta$. The regression model consists of two blocks. In the first block all four peri-urbanisation variables are included into an OLS regression model. The location determinants are in- tegrated within the second block of the model as control variables. Due to incomprehensive understanding of the location-farm adaptation-relationship (Pfeifer et al., 2009), a stepwise regression was applied here as a straightforward method to reduce the number of variables. The comparison of the regression models which only include the first block (peri-urbanisation) and models which include both blocks (peri-urbanisation and location) enhances the interpretive extent, as collinearities between the peri-urbanisation and location determinants can be revealed.

\section{Results}

\section{Spatial pattern of peri-urbanisation}

The four peri-urbanisation processes were analysed regarding their spatial pattern considering the distance to the centre of Copenhagen, the population density and natural amenities in the respective municipality (Table 3 ). The processes show a diverse spatial pattern in the case area.

The processes of ex- and anti-urbanisation features a clear correlation with the distance to Copenhagen. Whereas ex-urbanisation is found close to the city of Copenhagen, the latter one is rather concentrated in more remote rural areas. Apart of that, the other two do not show a significant correlation with distance to Copenhagen, although an interpretation of the allocation maps (Figure 2) reveals a concentration of displaced-urbanisation in many locations 
Table 3: Correlation analysis of spatial distribution of peri-urbanisation and location determinants.

\begin{tabular}{|c|c|c|c|c|}
\hline & $\begin{array}{c}\text { Displaced- } \\
\text { urbanisation } \\
\text { 1986-2006 } \\
\text { (std. value) }\end{array}$ & $\begin{array}{c}\text { Ex-urbanisa- } \\
\text { tion 1986-2006 } \\
\text { (std. value) }\end{array}$ & $\begin{array}{c}\text { Anti- } \\
\text { urbanisation } \\
\text { 1986-2006 } \\
\text { (std. value) }\end{array}$ & $\begin{array}{c}\text { Hidden- } \\
\text { urbanisation } \\
\text { 1986-2006 } \\
\text { (std. value) }\end{array}$ \\
\hline Distance to Copenhagen in $\mathrm{km}$ & n.s. & $-0.696 * *$ & $0.541 * *$ & n.s. \\
\hline Population density 2000 in inh. $/ \mathrm{km}^{2}$ & $-0.366^{* *}$ & n.s. & $-0.454 * *$ & $0.282 * *$ \\
\hline Share of coastal area ( $1 \mathrm{~km}$ buffer) in $\%$ & $-0.363 *$ & n.s. & $0.518 * *$ & n.s. \\
\hline Share of forest area in 2000 in \% & n.s. & $-0.241 *$ & n.s. & n.s. \\
\hline Share of water and wetland area in 2000 in \% & n.s. & n.s. & n.s. & n.s. \\
\hline Area share of clay-rich soils in $\%$ & n.s. & n.s. & n.s. & n.s. \\
\hline Standardized value of displaced-urbanisation 1986-2006 & & $0.477 * *$ & n.s. & $-0.665^{* *}$ \\
\hline Standardized value of ex-urbanisation 1986-2006 & & & n.s. & $-0.509 * *$ \\
\hline Standardized value of anti-urbanisation 1986-2006 & & & & $-0.234^{*}$ \\
\hline Standardized value of hidden-urbanisation 1986-2006 & & & & \\
\hline
\end{tabular}

*significance level by $\mathrm{p}<0.1 ; * *$ significance level by $\mathrm{p}<0.05 ;$ n.s. $=$ not significant

in medium distance from Copenhagen. Hidden-urbanisation relates to population density as it is concentrated in some municipalities close to Copenhagen as well as in small and medium-sized towns across the region. The bio-physical location determinants account for only partial correlations to peri-urbanisation. The share of coastal area in a municipality correlates positively with anti-urbanisation, mainly representing retirement migration. Displaced-urbanisation shows a slightly negative relation to coastal area as ex-urbanisation and forest area does. Both, water and wetland areas as well as the allocation of fertile clay-rich soils are not significantly correlated with any form of peri-urbanisation. Assessing the spatial interrelationship of the different periurbanisation types reveals a distinctive allocation of each of the processes, despite some spatial overlapping. Particularly hidden urbanisation is concentrated in municipalities which are little subject to other types of peri-urbanisation.

\section{Spatial relationships between peri-urbanisation and multifunctional farm adaptation}

The influence of the four peri-urbanisation processes and the location determinants are represented by regression models for each of the six farming variables. The consideration of the corrected $\mathrm{R}^{2}$ is meaningful here, as it balances the improvement effect of the model quality with increasing complexity of the model and indicated more clearly the significance of additional predictor variables. As a general finding, the various models are characterised by partly strong differences regarding the explanatory power as indicated by the corrected $\mathrm{R}^{2}$ values (Table 4 ). The model quality varies substantially between the farm adaptation measures. Particularly agri-environmental management practices and diversification into leisure and lifestyle activities are featured by good model performances, whereas the spatial distribution of specialised high-value crop cultivation (horticulture) is only insufficiently explained. The differences of the explanatory power are even more pronounced between regression models which include location determinants or not. There is a significant increase of all model coefficents, as the spatial framework conditions seem to comprise of a strong influence on farm adaptation strategies. Especially for recreation and leisure related farm adaptation - horsekeeping (corr. $\mathrm{R}^{2}=71 \%$ ) and small-scale farming (corr. $\mathrm{R}^{2}$ $=94 \%$ ) but also extensive grassland management (corr. $\mathrm{R}^{2}$ $=98 \%$ ), good model accuracies were accomplished. Partly the coefficients of the predictor variables differ between the two models for as mutual collinearities exist. This is e.g. the case of the distance to Copenhagen and especially exurbanisation, a peri-urbanisation process which commonly occurs in the proximity of the metropolitan area. For all regression models, at least one peri-urbanisation process contributes significantly to the value distribution of the dependent variable.

As indicators for environmental-friendly farming practices, organic production and the application of extensive grassland production and has been selected. Figure 3 gives 


\section{Peri-urbanisation around Copenhagen}

Data for municipalities, 1986-2006

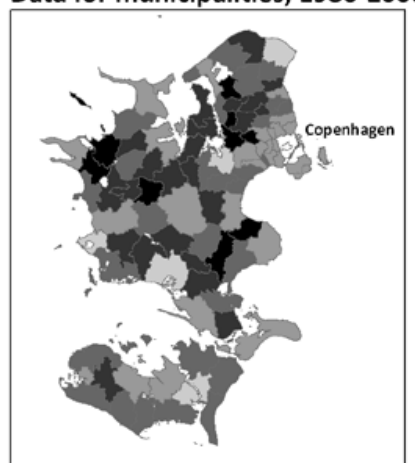

Displaced-urbanisation

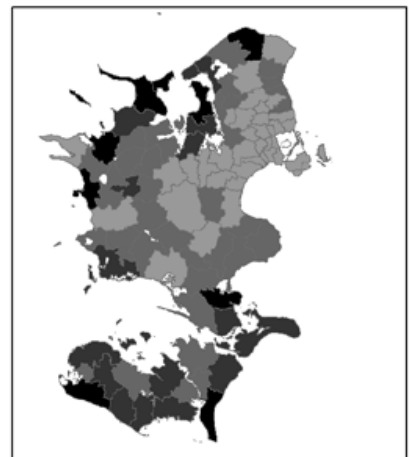

Anti-urbanisation

$\mid<-1.5 \quad-1.5--0.5$

Standard deviation from regional average

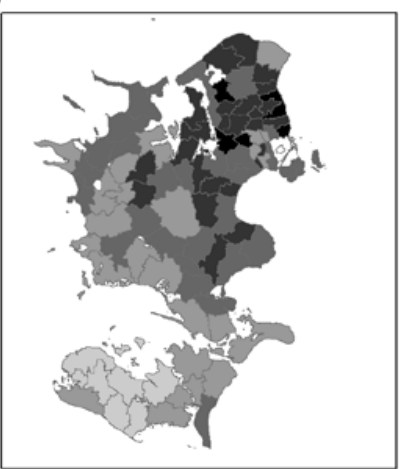

Ex-urbanisation

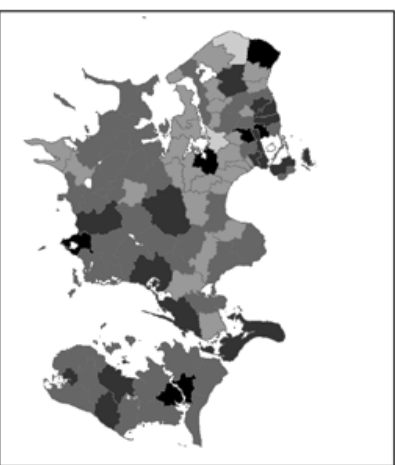

Hidden-urbanisation

$-0.5-0.5$

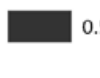

$5-1.5$

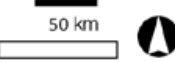

\ Figure 2: Spatial distribution of peri-urban migration processes.

Figure 3: Spatial distribution of farming indicators.

an over view of the value distribution of all farming indicators. The general explanatory power of the regression model for extensive grassland production is much larger (corr. $\mathrm{R}^{2}=98 \%$ ) than for organic farming (corr. $\mathrm{R}^{2}=58 \%$ ). The latter one is less sensitive for peri-urban developments and location framework conditions. If taken isolated, a considerable positive influence of ex-urbanisation can be found. When including location determinants this relationship is covered by a strong dependency from population

\section{Farming structure around Copenhagen}

Data for municipalities

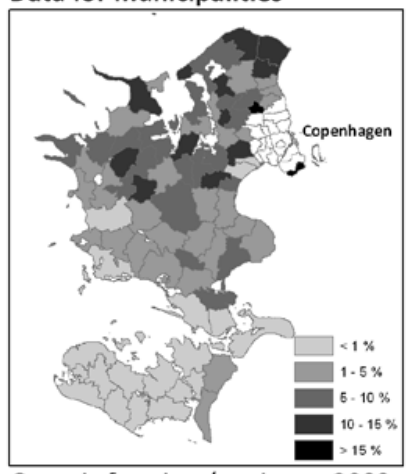

Organic farming / agri area 2003
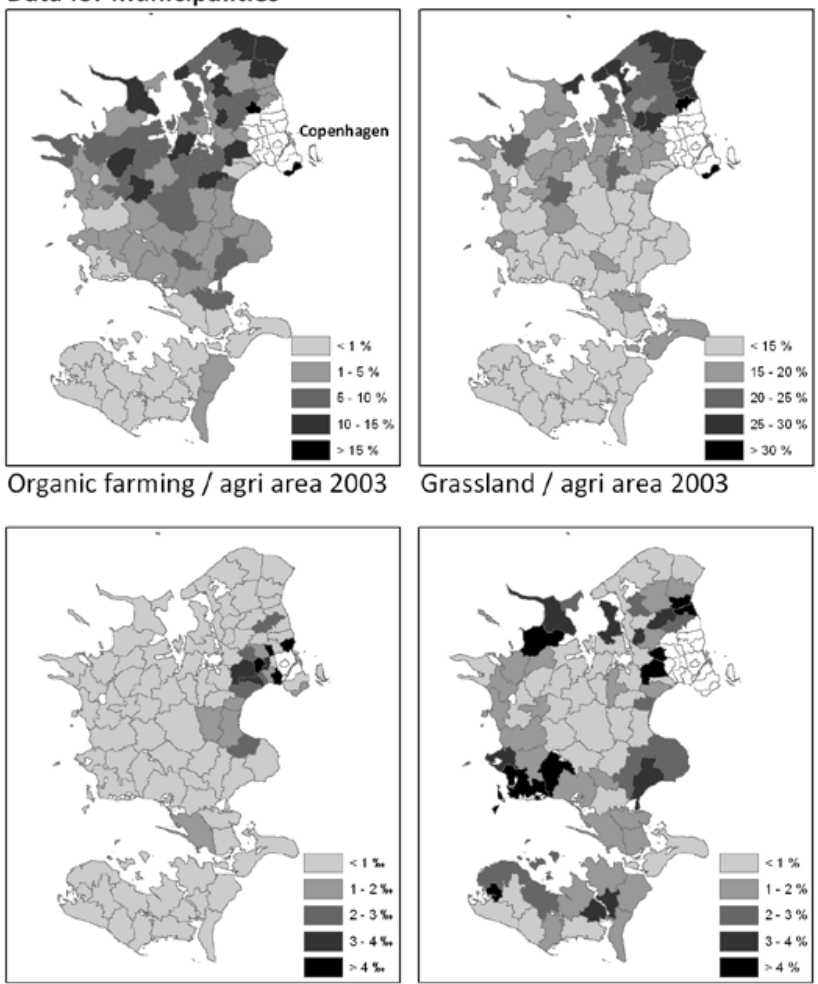

Green houses / agri area 2005

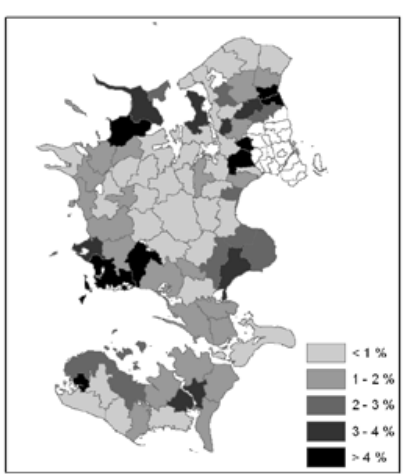

Horticulture / agri area 1999

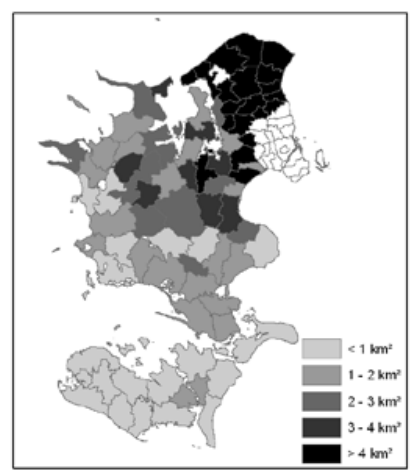

Horses / argi area 1999

no data

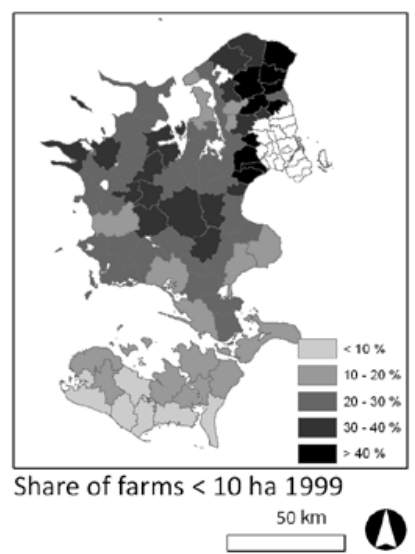

density and displaced (positive) and anti-urbanisation (negative) account for an enhanced influence. In addition, for organic farming and grassland cultivation, comprehensive relationships exist to almost all location determinants with population density accounting for the strongest positive relationship. In contrast, soil quality seems to be a less determining location variable for farm adaptation strategies in the peri-urban - the share of clay-rich soils shows the strongest opposing relationship. 
Table 4: OLS Regression models to describe the dependency of farming system differences from peri-urbanisation.

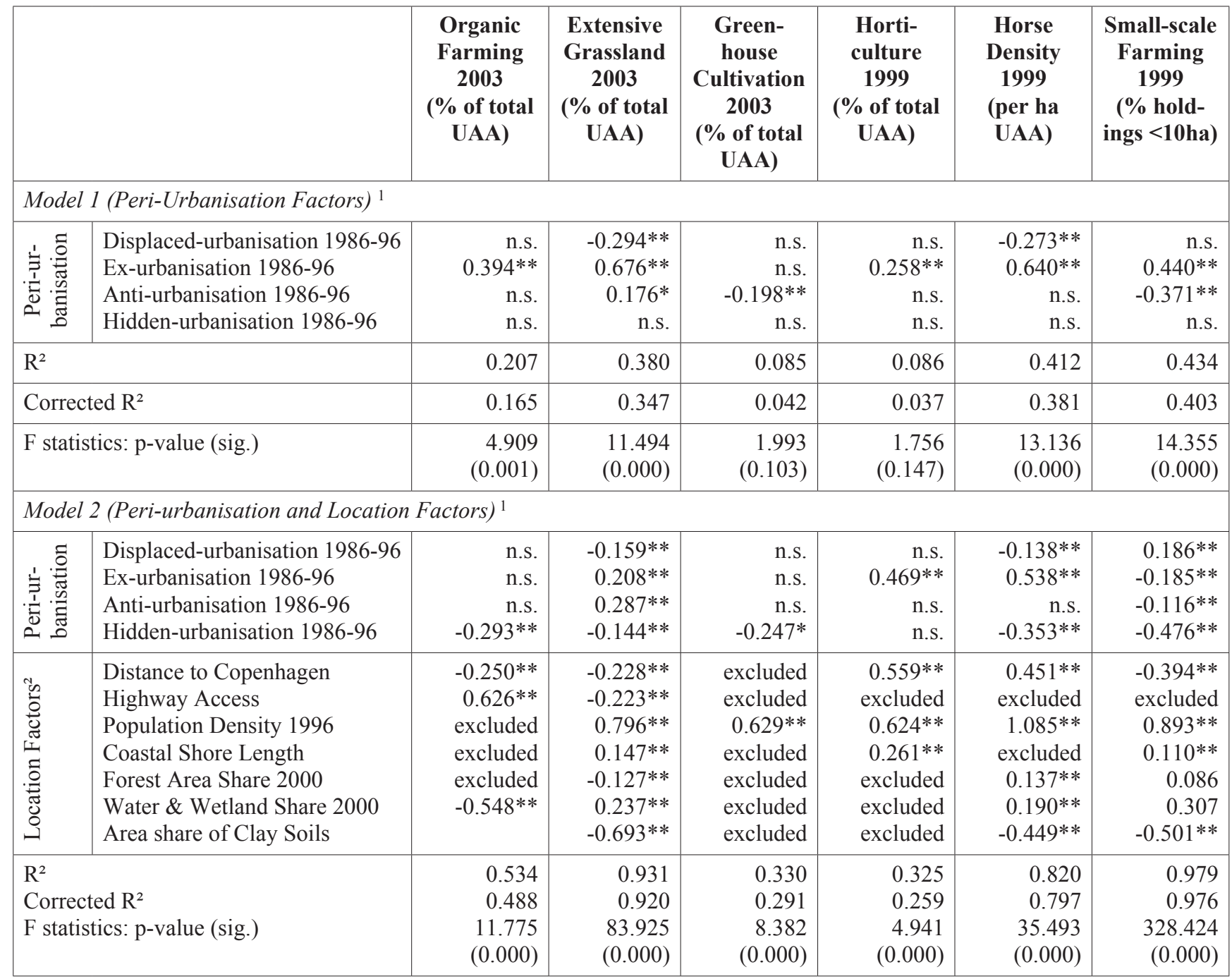

$\mathrm{UAA}=$ Utilised Agricultural Area

${ }^{1}$ standardised Coefficients Beta; ${ }^{2}$ Location factors in Model 2 have been excluded from the regression model, if f likelihood outside $0.05-0.10$

*significance level by $\mathrm{p}<0.1 ; * *$ significance level by $\mathrm{p}<0.05 ; \mathrm{n} . \mathrm{s}$. $=$ not significant

The distribution of horticulture and greenhouse production has been used as representatives for farming specialisation on horticultural produces with high gross margins per cultivated area, such as vegetables or ornamental plants. For both variables the value distribution is characterised by a regional concentration pattern in the south of the region and the direct urban fringe of Copenhagen in the case of horticultural production. Otherwise population density represents a highly influential factor for greenhouse cultivation and horticulture. Beyond that, none of the peri-urbanisation processes show positive coefficients indicating a surprisingly low or non-existent spatial relationship. Both regres- sion models generally account for only limited explanatory power for the value distribution of the depending variable.

Indicators representing lifestyle and leisure-oriented farming styles are also characterised by rather strong regional disparities. Farm sizes tend to decline from South to North of the case study region. Whereas on the islands of Lolland and Falster, municipalities are characterised by comparably large-scale farming, low values are revealed for the North of Sjaelland. In turn, municipalities in this area feature high stocking rates of horses. The model performances for horse density and small-scale farming indicate comprehensiveness of explanation through peri-urban- 
isation pattern and location determinants, although both variables differ substantially regarding the dependency from peri-urbanisation. Prevailing ex-urbanisation is positively related to horse density, but negatively to small-scale farming. There is a clear indication for a spatial divergence between hidden-urbanisation and both recreation-related farming variables. However, the peri-urban influence is clearly overshadowed by location determinants. Again, the population density has an enormous influence on farmscale and horse density. A positive correlation to water and wetland location is little surprising amongst the natural amenities which determine small-scale farming. Also the absence of small-scale farming in areas rich in soils with above average share of clay was expected, as such are traditional locations for competitive large scale farming,

\section{Discussion}

\section{Spatial pattern of peri-urbanisation}

Peri-urbanisation is only vaguely defined, usually encompassing urban transformations which take place outside the urban cores (Madsen et al., 2010; Piorr et al., 2011). This paper builds upon the idea to distinguish four periurbanisation processes representing different forms of inmigration and lifestyle changes of residents. The spatial pattern of peri-urbanisation is strongly influenced by determinants which characterises the heterogeneity of the case study area. If taken correlation results into consideration, it is recognised that particularly variables which describe economic potential and social integration of the location within the urban agglomeration are more important than natural amenities, such in the case of income-driven exurbanisation which takes place close to the city centre, but without any significant relationship to coastal, water or forest area extent. The retirement type of anti-urbanisation intending the purpose of seeking calm and rural environments occurs mainly in municipalities with low population densities and distance to the central city prevail. The particular importance of the coastal location for the retirement migration confirms previous observations in other regions (Zasada et al., 2010). The positive correlation between population density and hidden-urbanisation might be traced back to the prevalence of this peri-urbanisation type around regional centres of the case study region. Areas without significant degree of peri-urbanisation are either located close to Copenhagen or belong to independent small town areas and therefore are already part of an urban agglomeration. They also represent traditional rural areas, often in a peripheral location, which only sparsely affected of peri-urbanisation yet. The strong spatial dependency of the different peri-urbanisation processes from location determinants make the interpretation of the regression modelling results more difficult, particularly in terms of comparison of the model which exclusively refers to peri-urbanisation as explanatory variables and the one which also integrates location variables.

\section{Multifunctional farm adaptation}

In order to find indication about the influence of peri-urbanisation and other location determinants on the spatial distribution of multifunctional farm adaptation a regression analysis of selected farm type and farm management variables was carried out. Despite statistical abstraction and generalisation at the municipal level, the application of a peri-urbanisation model which differentiates four distinct socio-economic development processes has proven meaningful, as significant results were found. Considerable influence differences between the explanatory variables exist regarding significance, strength and even direction of influence.

In-migration processes of younger milieus and families, but also educated and affluent residents, represented by displaced and to a larger extent ex-urbanisation, contribute to a growing consumer potential and purchasing power combined with an appreciation for rural life attributes, attitudes and products. Therefore it is not surprising that particularly the provision of goods and services from farming which are sensitive for local consumer demand - equine services or regional and fresh products from horticulture and organic cultivation - can be found in municipalities, where these kinds of peri-urbanisation take place. This corresponds with previous findings which acknowledged the relevance of direct consumer-producer-relationships, either for organic vegetable production (Goy \& Maack, 2008) or for horse-keeping (Bailey et al., 2000). These spatial compliances need to be seen against the background of the densely populated urban fringe location, as particularly population density account for a substantial effect within the regression modelling. However, there is indication that farm adaptation and diversification processes are fostered. Accordingly, in-migration into the peri-urban seems not only to lead to increased population density, but also to an overproportional concentration of consumers that represent target groups for farmers with adaptive strategies. The positive relationship to grassland cultivation remains somewhat surprising and in contrast to research results from Van Huylenbroeck et al. (2005), who address land 
suitability issues as drivers for extensive farming schemes in proximity to the city. Research results from Switzerland, however, have confirmed the prevalence of extensive production schemes in urbanised areas, without distinguishing different types of peri-urbanisation (Tobias et al., 2005).

Retirement migration related anti-urbanisation entails no significant or even negative relationship to multifunctional farming activities, except from prevailing extensive grassland management. It can be argued that landscape management measures contributing to the amenity value of the landscape, attract this type of amenity-driven retirement migration. Hidden urbanisation, identified by successive increase of out-commuters of active population, differs substantially from other types of peri-urbanisation regarding the influence on multifunctional farming. Municipalities which are subject to hidden urbanisation are characterised by a general under-representation of multifunctional farming strategies. The absence of further consumer potential affects particularly local market-sensitive activities, such as horse-keeping or organic farming. On the other hand large farm sizes in hidden urbanisation areas are rather unexpected. Kristensen (1999) provides some reasoning, as he revealed, that part-time and hobby farmer tend to rent land to remaining farms, leading to stable farm sizes despite decrease of full-time farming. Beyond other factors that trigger structural change, the increasing farm size might be a result of more land availability due to farmers quitting farm activities part time or completely in order to take up employment in town - and becoming part of the hidden urbanisation community.

Discussing the statistical analysis results on the relationship between peri-urbanisation and farming, the effects of location determinants are already recognised. The framework conditions not only correlate significantly with the spatial distribution of peri-urbanisation, they also influence the farming practices on top of that. It is not surprising that in areas with fertile clay-rich soils, such in the east and south of the Sjaelland region extensive grassland and horse-keeping is less prevalent. But there are even more generally negative correlations between soil fertility and multifunctional farming variables. Going multifunctional is therefore obviously an adaptation strategy for farms in less advantages site conditions. The same applies for the effect of natural amenities on the concentration of leisure oriented farming. Multifunctional farming orientations decrease with distance to the regional centre and decreasing population density. Alongside with soil quality, Pfeifer et al. (2009) suggest also other farm operational factors. Institutional framework conditions, such as local and re- gional policies have been put forward as important factor to encourage farmers to diversify and participate in environmental programmes (Vandermeulen et al., 2006). Not least, the importance of traditional growing regions for horticulture and greenhouse production, such in some municipalities of the Copenhagen region has be taken into consideration for today's production allocation.

\section{Conclusion}

In this paper, the spatial relationship between peri-urbanisation as an in-migration process of urban dwellers into the rural hinterland as well as socio-economic changes of local residents on the one hand and the impact on and response of farming in the region around Copenhagen on the other hand was examined. Regarding the first research question, distinctive spatial differences between the peri-urbanisation processes - displaced-, ex-, anti- and hidden-urbanisation were found. The analysis of the socio-economic transitions in the Copenhagen region revealed that peri-urbanisation is spatially constituted heterogeneously at a local level and very much determined by location determinants. Proximity to Copenhagen as the central city in the region and population density has proven relevant for the spatial distribution, whereas natural amenities play a much less important role. Regarding the second research question, it was found that peri-urbanisation around Copenhagen cannot be seen as a uniform process which influences farm structure and management practises in the rural countryside. Instead, there is indication that the spatial representation of the different peri-urbanisation sub-processes accounts for a substantial influence on farm adaptation strategies towards multifunctionality. Increasing income levels, changing lifestyles and age-structure, related to changing consumer demands for local agricultural goods and services, such as organic food or leisure services obviously contribute to a multifunctional transition of farming in specific locations.

Nevertheless, it is necessary to highlight, that farming in general, but multifunctional adaptation more specifically are strongly depending of the political framework conditions, like the European agricultural and rural development policy. Particularly Rural Development Programmes set incentives for such adaptations. But they do not yet sufficiently consider the specific role and potentials of peri-urban areas and sometimes even exclude them from eligibility (Piorr et al., 2011). However, the different socioeconomic processes attached to peri-urbanisation transforms framework conditions for farming and thus farming 
itself. Therefore its preservation for the future regional development requires carefully targeted policy and support which takes the specific peri-urban quality of agriculture into consideration.

\section{Acknowledgements}

This work has been carried out within the FP6 Integrated Project PLUREL - Peri-urban Land Use Relationships, funded by the European Commission, Directorate-General Research, Contract No. 36921. The authors would like to thank two anonymous reviewers for helpful suggestions and discussions.

\section{References}

Aner, L.G. (2009): Udflytninger fra København. Børnefamiliers udflytninger og bostedsvalg $\mathrm{i}$ et hverdagslivsperspektiv. PhD disseration. Copenhagen, Faculty of Natural Sciences, University of Copenhagen and Centre for Strategic Urban Research. [in Danish]

Antrop, M. (2000): Changing patterns in the urbanised countryside of Western Europe. Landscape Ecology 15(3): 257-270.

Antrop, M. (2004): Landscape change and the urbanisation process in Europe. Landscape and Urban Planning 67(1-4): 9-26.

Bailey, A., Williams, N., Palmer, M. \& Geering, R. (2000): The farmer as service provider: the demand for agricultural commodities and equine services. Agricultural Systems 66(3): 191-204.

Beauchesne, A. \& Bryant, C. (1999): Agriculture and Innovation in the Urban Fringe: The Case of Organic Farming in Quebec, Canada. Tijdschrift voor Economische en Sociale Geografie 90(3): 320-328.

Bertrand, N. (2007): Introduction: ESDP Ideals and the Inheritance of Rural Planning Failures. Pp. 1-18 in: Bertrand, N. \& Kreibich, V. (eds.): Europe's city-regions competitiveness: Growth regulation and peri-urban land management. Assen, Royal Van Gorcum.

Briquel, V. \& Collicard, J.-J. (2005): Diversity in the Rural Hinterlands of European Cities. Pp. 19-40 in: Hoggart, K. (ed.): The City's Hinterland - Dynamism and Divergence in Europe's Peri-Urban Territories. Adlershot, Ashgate.

Bryant, C.R., Deslauriers, P. \& Marois, C. (1992): Diversification strategies in agriculture in the rural-urban fringe. Pp. 95-113 in: Mohammad, N. (ed.): Spatial Dimensions of Agriculture. New Dehli, Concept Publishing Company.

Busck, A.G., Pilgaard Kristensen, S., Præstholm, S., Reenberg, A. \& Primdahl, J. (2006): Land system changes in the context of urbanisation: Examples from the peri-urban area of Greater Copenhagen. Geografisk tidsskrift-Danish Journal of Geography 106(2): 21-34.

Busck, A.G., Kristensen, S.P., Præstholm, S. \& Primdahl, J. (2008): Porous landscapes - The case of Greater Copenhagen. Urban Forestry and Urban Greening 7(3): 145-156.

Cabus, P. \& Vanhaverbeke, W. (2003): The economics of rural areas in the proximity of urban networks: evidence from Flanders. Tijdschrift voor Economische en Sociale Geografie 94(2): 230-245.

Caruso, G. (2001): Peri-urbanisation: the situation in Europe. A bibliographical note and survey of studies in the Netherlands, Belgium, Great Britain, Germany, Italy and the Nordic countries. Report prepared for DATAR, France.

CEMAT (2007): Spatial development glossary. Strasbourg, Council of Europe.

Champion, A.G., Fielding, A.J. \& Keeble, D. (1989): Counterurbanisation in Europe. The Geographical Journal 155: 52-80.

Danmarks statistik (1989): Statistiske efterretninger: Arbejdsmarked. Copenhagen. [in Danish]

Danmarks statistik (2000): Landbrug 1999: statistik om landbrug, gartneri og skovbrug. Copenhagen. [in Danish]

Danmarks statistik (2010): Statistikbanken. Available from: www.dst.dk

Elgaker, H. \& Wilton, B. (2008): Horse farms as a factor for development and innovation in the urbanrural fringe with examples from Europe and Northern America. Forest \& Landscape Working Papers 27.

Errington, A. (1994): The Peri-urban Fringe - Europe's Forgotten Rural-Areas. Journal of Rural Studies 10(4): 367-375.

European Commission (2003): Agriculture and the environment. Brussels, European Commission.

European Environment Agency (2010): Corine Land Cover 1990 and 2006. The European Topic Centre on Land Use and Spatial Information. Available from www.eea. europa.org

Goy, I.A. \& Maack, K. (2008): Bundesweite repräsentative Erhebung und Analyse der verbreiteten Produktionsund Vermarktungssysteme und Aufbau eines bundes- 
weiten Praxis-Forschungs-Netzwerkes im ökologischen Gartenbau - Situation des ökologischen Gartenbaus in Deutschland. Hannover, Leibniz Universität Hannover. [in German]

Halfacree, K. \& Boyle, P. (1998): Migration, rurality and the post-productivist countryside. Pp. 1-20 in: Halfacree, K. \& Boyle, P. (eds.): Migration into rural areas: theories and issues. Chichester, Wiley.

Halliday, J. \& Coombes, M. (1995): In search of counterurbanisation: Some evidence from Devon on the relationship between patterns of migration and motivation. Journal of Rural Studies 11(4): 433-446.

Herslund, L. \& Fertner, C. (2010): Anti-urbanisation as development chance for rural areas. In-migration and self-employed business in the countryside around Copenhagen. Book of Abstracts, 72, Proceeding of the Conference 'Managing the Urban Rural Interface', University of Copenhagen, Copenhagen, Denmark, 19-22 October 2010.

Ilbery, B., Holloway, L. \& Arber, R. (1999): The Geography of Organic Farming in England and Wales in the 1990s. Tijdschrift voor Economische en Sociale Geografie 90(3): 285-295.

Institut for Jordbrugsproduktion og Miljø: DJF geodata. Det Jordbrugsvidenskabelige Fakultet. Aarhus Universitet. [in Danish]

Jongeneel, R.A., Polman, N.B.P. \& Slangen, L.H.G. (2008): Why are Dutch farmers going multifunctional? Land Use Policy 25(1):81-94.

Kort \& Matrikelstyrelsen: Top10DK (Topographical map database of Denmark, 1:10000). Available from: www.kms.dk/English/Maps+and+Topography/ Topographic+Data/Denmark+1-10000/

Kristensen, S.P. (1999): Agricultural land use and landscape changes in Rostrup, Denmark: processes of intensification and extensification. Landscape and Urban Planning 46(1-3): 117-123.

Kristensen, L. (2001): Agricultural change in Denmark between 1982 and 1989: the appearance of post-productivism in farming? Geografisk tidsskrift 101(1): 77-86.

Lewan, N. (1969): Hidden Urbanisation in Sweden. Tijdschrift Voor Economische en Sociale Geografie 60(3): 193-197.

Madsen, M.F., Kristensen, S.B.P., Fertner, C., Busck, A.G. \& Jørgensen, G. (2010): Urbanisation of rural areas: A case study form Jutland, Denmark. Geografisk Tidsskrift-Danish Journal of Geography 110(1): 47-63.
Miljøministeriet: Danmarks Miljøportal (The Danish Nature \& Environment Portal). Available from: http://kort. arealinfo.dk

Mitchell, C.J.A. (2004): Making sense of counterurbanisation. Journal of Rural Studies 20(1): 15-34.

Nielsen, T.A.S. \& Hovgesen, H.H. (2005): Urban fields in the making: New evidence from a Danish context. Tijdschrift Voor Economische en Sociale Geografie 96(5): 515-528.

Péron, J.Y. \& Geoffriau, E. (2007): Characteristics and Sustainable Development of Peri-Urban Vegetable Production in Europe. ISHS Acta Horticulturae, International Symposium on Horticultural Plants in Urban and PeriUrban Life: 159-170.

Pfeifer, C., Jongeneel, R.A., Sonneveld, M.P.W. \& Stoorvogel, J.J. (2009): Landscape properties as drivers for farm diversification: A Dutch case study. Land Use Policy 26(4): 1106-1115.

Piorr, A., Müller, K., Happe, K. \& Uthes, S. (2007): Agricultural management issues of implementing multifunctionality: commodity and non-commodity production in the approach of the MEA-Scope project. Pp. 167-181 in: Mander, Ü., Wiggering, H. \& Helming, K. (eds.): Multifunctional Land Use: Meeting Future Demands for Landscape Goods and Services. Berlin, Springer.

Piorr, A., Ravetz, J. \& Tosics, I. (2011): Peri-urbanisation in Europe: Towards a European Policy to Sustain UrbanRural Futures. A Synthesis Report. Frederiksberg, University of Copenhagen, Academic Books Life Sciences.

Primdahl, J. (1999): Agricultural landscapes as places of production and for living in: owner's versus producer's decision making and the implications for planning. Landscape and Urban Planning 46(1-3): 143-150.

Præstholm, S. \& Kristensen, S.P. (2007): Farmers as initiators and farms as attractors for non-agricultural economic activities in peri-urban areas in Denmark. Geografisk Tidsskrift-Danish Journal of Geography 107(2): 13-27.

Præstholm, S., Reenberg, A. \& Kristensen, S.P. (2006): Afforestation of European landscapes: How do different farmer types respond to EU agri-environmental schemes? GeoJournal 67(1): 71-84.

Quetier, F.F. \& Gordon, I.J. (2003): 'Horsiculture': How important a land use change in Scotland? Scottish Geographical Journal 119: 153-158.

Robinson, G.M. (1990): Conflict and change in the countryside. Rural society, economy and planning in the developed world. London, Belhaven Press.

Spectorsky, A.C. (1955): The exurbanites. Philadelphia, Lippincott. 
Tobias, S., Nuesch, A., Nebel, R. \& Guilmain, A. (2005): Suburbane Landwirtschaft oder Landschaftsmanagement? Agrarforschung 12(7): 306-311. [in German]

Van Berkel, D.B. \& Verburg, P.H. (2010): Sensitising rural policy: Assessing spatial variation in rural development options for Europe. Land Use Policy 28(3): 447-459.

Van den Vaart, J.H.P. (1991): Conversion of farmsteads: Hidden urbanisation or a changing rural system? in: van Oort G.M.R.A., van den Berg, L.M., Groenendijk, J.G. \& Kempers, H.H.M. (eds.): Limits to Rural Land Use: Proceedings of an International Conference Organised by the Commission on Changing Rural Systems of the International Geographical Union, Amsterdam, Netherlands, 21-25 August 1990.

Van Huylenbroeck, G., Van Hecke, E., Meert, H., Vandermeulen, V., Verspecht, A., Vernimmen, T., Boulanger, A. \& Luyten, S. (2005): Development strategies for a multifunctional agriculture in peri-urban areas - Summary. Brussels, Belgian Science Policy.

Van Huylenbroeck, G., Vandermeulen, V., Mettepenningen, E. \& Verspecht, A. (2007): Multifunctionality of Agriculture: A Review of Definitions, Evidence and Instruments. Living Reviews in Landscape Research 1(3): 1-38.

Vandermeulen, V., Verspecht, A., Huylenbroeck, G., Meert, H., Boulanger, A. \& v. Hecke, E. (2006): The importance of the institutional environment on multifunctional farming systems in the peri-urban area of Brussels. Land Use Policy 23(4): 486-501.

Wilson, G. (2007): Multifunctional agriculture: a transition theory perspective. Wallingford, CABI International.

Zasada, I., Alves, S., Müller, F. C., Piorr, A., Berges, R. \& Bell, S. (2010): International retirement migration in the Alicante region, Spain: process, spatial pattern and environmental impacts. Journal of Environmental Planning and Management 53(1): 125-141.

Zasada, I. (2011): Multifunctional peri-urban agriculture - A Review of societal demands and the provision of goods and services by farming. Land Use Policy 28(4): 639-648. 